\section{Rikke Schubart: Med vold og magt - actionfilm fra Dirty Harry til}

The Matrix. København: Rosinante, 2002, 495 sider.

Lad det være sagt med det samme: det er et imponerende pionerarbejde, Rikke Schubart (RS) har præsteret med sin bog om actionfilmen og dens helte. At skrive knap 500 sider om en genre, der stort set ikke har været systematisk behandlet før, vækker i sig selv respekt. Men lad det også straks være klart, at Med vold og magt også er en bog, der ægger til diskussion.

RS lægger for med et forholdsvis kort, introducerende kapitel om Amerika og om actionsfilmens kendetegn. Herefter præsenterer hun i de følgende 15 kapitler actionfilmen i de tre årtier, den (indtil videre?) har fandtes. Der er fem kapitler om actionheltene i 70'erne (Eastwoods Dirty Harry, Charles Bronson, Blaxploitation, Bruce Lee og Chuck Norris), fem kapitler om actionheltene i 80'erne (Stallone, Schwarzenegger, Mel Gibson, Eddie Murphy \& Bruce Willis og Van Damme) og fem kapitler om 90'erne, hvor billedet skifter noget, og Steven Seagal er ene om i sin egenskab af actionhelt at få et kapitel for sig selv.

Bogen er først og fremmest en actionfilmens kultur-, social- og recensionshistorie. Teoretisk henter RS sit stof fra traditionelle filmteoretiske stofområder som genre- og auteuranalyse, som hun i sine overvejende tematiske analyser ofte kombinerer med freudiansk psykoanalyse. Sidstnævnte dog ikke i originalaftapning - Freud selv figurerer ikke på litteraturlisten - men anskuet som især amerikansk filmteori - ofte i kønsforskningens lys - i tematiske læsninger har gjort det siden midten af 70'erne. Dertil skal lægges en antropologisk forståelse for det moderne Amerika og dets myter og lidt spredt gods fra bl.a. en håndfuld poststrukturalistiske franske tænkere: Girard (om syndebukken), Baudrillard (om tiden efter orgiet) og Deleuze (om masochismen).

Bogens overordnede pointe er, at actionfilmen dukkede frem i USA i det værditomrum, der opstod "efter orgiet" med 1960'ernes frigørelser og det mytologiske kollaps, de forårsagede - for nogle, burde man tilføje. Med konklusionens ord: "Oprindelig opstod actionfilmen af en krise i maskuliniteten og amerikanernes selvfølelse. I dag er amerikanernes tillid til egne værdier og til maskuliniteten stærkere end nogensinde, og genren er dermed blevet lige så overflødig som elitesoldaten Rambo i sit hjemland" (s. 434). Dermed kan bogen læses som den første gravskrift i actionfilmens mausoleum, og dog ... for RS slutter af med spørgsmålet "Men hvem ved - måske vil actionfilmens mytologiske frelserhelt vende stærkt tilbage for at ordne et nyt århundredes tabte krige?"

I bogens første kapitel præsenterer RS kort actionfilmens historie. En egentlig actiongenre udvikler sig først i 1968 - med tre film, skriver hun: "Bullitt (1968), The French Connection (1971) og Dirty Harry (1971)" (s. 16). De to af de tre film fra 1968 er altså fra ... 1971! Hvorfor Dirty Harry i øvrigt så kun er med på listen over de tre film fra 1971, der små 30 sider længere henne "markerer actionfilmens fødsel" (s. 45) - de to andre er Bruce Lees The Big Boss og blaxploitationfilmen Shaft-overrasker.

Uanset årstal og titler finder RS grundlæggende to konstituerende træk ved genren: actionscenen og actionhelten. Nok har der været actionscener i massevis af film før 1968, men den nye genre kan simpelthen ikke forstås udenom den "heftige" (s. 17) actionscene. Actionhelten og i særdeleshed det passions-plot, der knytter sig til ham (eller til hende, for der findes også kvindelige actionhelte) er det andet genrekonstituerende træk: i fire faser følger vi hans udstødelse (han bliver syndebuk), hans ofte nærmest tilfældige $u d v c e l g e l s e$, of ringen af ham (efter udført gerning bliver han 'slagtet' af sine overordnede, af sin regering) og endelig hans genopstandelse og hoevn. Det er denne gennemgående fortælling, der får RS til at tale om actionfilmen som den moderne tids frelsermytologi.

Strukturelle elementer som actionscene og actionhelt med tilhørende -plot ser imidlertid noget forskellige ud, alt efter f. eks. hvilken type actionhelt forskellige perioder har opereret med. Clint Eastwoods Dirty Harry og Charles Bronsons selvtægtsarkitekt (En mand ser rødt-filmene) er forskellige versioner af skraldemanden; ham, der rydder op i dét samfundsmæssige affald, hulbrystede politikere har ladet ligge i tiden efter orgiet. Bruce Lee er danseren, Stallones Rambo er en hardbody, Schwarzenegger bliver efterhånden til en stålhelt. Schubart er fremragende til at kategorisere og til at finde på håndfaste betegnelser for de forskellige aktualiseringer af actionhelten. Bogens uomtvistelige styrke ligger i dens historiske overblik og i dens overbevisende strukturering af en dynamisk genres historiske varianter. 
Som det til overflod er tilfældet i de talrige film, RS refererer og analyserer, er der good guys og bad guys også i fremstillingen. De allerbedste er asiaterne; dem, der kan se den ellers gennemamerikanske genre udefra: Bruce Lee som skuespiller og instruktør og instruktøren John Woo - indtil han kom til Hollywood altså. Men også de australske Mad Max-film - " actionfilmens bedste og mest intelligente apokalypsetrilogi" (s. 227) - og nogle af 70'ernes sorte helte, Shaft og den "fantastiske" (s. 310) Pam Griers "uimodståelige" film hører til på RS' positivliste. Omvendt er markeret politisk reaktionære actionhelte som Chuck Norris, Jean-Claude Van Damme og Steven Seagal på den sorte liste.

Når en medieforsker i så høj grad som i tilfældet her tager stilling for og imod sit materiale, vækker det undren. For som medieforsker skal man analysere og kontekstualisere - eller hvad? Det $g ø r$ RS, men det bliver til rigtig mange anmeldelser i bogens løb. Skal man anmelde inden for en videnskabelig diskurs, bør man i det mindste eksplicitere sine kriterier. Og dét gør RS ikke, ikke altid i hvert fald. Det fremgår f. eks. hverken, hvad der gør Clint Eastwoods film Pink Cadillac og The Rookie til "makværker" (s. 50), eller hvad der får RS til at tale om Paul Verhoevens "smågeniale" (s. 212) RoboCop. Og hvorfor skal der stå, at actionfilmen "heldigvis" får humor i firserne? (s. 143)

Det fremgår af bogens første linjer, at den bygger på RS's ph.d.-afhandling (som jeg ikke har læst). Hvor ph.d.-afhandlingen har en akademisk offentlighed som sit veldefinerede publikum, er det straks sværere at se, hvem der er modtageren for denne mere populære fremstilling, hvor "alle de teoretiske mellemregninger" (s. 7) - er luget bort. RS tegner ikke eksplicit et billede af sin forventede læser, men hvem andre end særdeles læsevante hoveder kaster sig over en bog på knap 500 sider med en litteraturliste på vel omkring 250 titler og 365 slutnoter? Vi er vel ovre i kategorien "den intellektuelle tandlæge". Der er bestemt masser af stof for denne læser, men - i tillæg til sin anmeldetvang - er bogen sine steder skrevet $i$ et ubærligt friskfyrsagtigt sprog, som $m a ̊$ ramme ved siden af. At ord som lort, pik og fisse indgår i bogens vokabularium ligger i sagens natur, for så vidt de indgår i filmenes jargon, og kan man ikke klare dén most, har man nok kun set actionfilm ved et tilfælde og vil næppe være meget interesseret $i$ at læse om genren. Anderledes med det friskfyrsagtige. Lad mig tage et par eksempler.
Først fra gennemgangen af det kanoniske actionfilmplot. Skurkens motiv er, skriver RS, "ikke så vigtigt. Det vigtigste er at få handlingen på skinner og helten ud og sparke røv" (s. 22). Eller hvad med den her om en scene i en stripscene $\mathrm{i}$ Barb Wire: "Publikum kom, så, og ikke et skridt var tørt". Og hvad med et udtryk som "bøsseri" - er det gangbart eller bare popsmart? Eller "negerfalset" om Eddie Murphys stemme - påtaget politisk ukorrekthed? Eller - som et sidste eksempel - i en opsummering af udviklingen efter computerteknologiens indtog i actionfilmen: "Og helt ærligt, eksplosionerne bliver uinteressante i halvfemserne. Publikum gider trods alt ikke sidde i samme rutsjebane dagen lang" (s. 419). Says who?

Filmenes forhold til publikum er i det hele taget et af bogens ømme punkter. Publikum er for det meste enten RS selv eller også er det amerikanske eller danske anmeldere og kritikere, der i filmenes samtid har reageret skriftligt og professionelt på filmene. Det er næppe muligt at lave de historiske receptionsanalyser, der kunne gøre publikumsbegrebet både bredere og mere relevant, men man savner overvejelser over publikums diversitet og over, hvad filmenes publikum fik ud af de mange og meget forskellige actionhelte.

"Ingen symboler er tilfældige på film, især ikke kristne symboler" står der i gennemgangen af Clint Eastwoods Sudden Impact (s. 70). Det er formentlig en fejlskrivning, der nok får én til at trække lidt på smilebåndet, men citatet peger på bogens grundlæggende læsestrategi: symptomallæsningen. Den gennemgående teoretiske bagtekst for analyserne er psykoanalysen. Som nævnt er Freud selv ikke på litteraturlisten, men alligevel må man tit læse om, at noget i psykoanalysen forholder sig sådan og sådan, ligesom man får at vide, at f. eks. de store muskler og heltenes evne til at vende tilbage efter udstødelsen har med erektion at gøre: "I rækken af nedlagte modstandere finder vi en ønsketænkning om evig rejsning, evig potens. [Bruce] Lee kan 'rejse sig' igen og igen" (s. 124). Dén analysestrategi sender mig direkte 30 år tilbage i tiden - til dansktimerne i gymnasiet og den psykoanalytiske læsning, min - i øvrigt fremragende - dansklærer præsenterede af Juggernaut. Men det var dengang og på et andet niveau. Siden har bl.a. David Bordwell sønderbombet den psykoanalytiske læsestrategi, og om ordspillet skrev han i "Making Meaning" for 15 år siden: "The critic can create a cue by making a pun" skrev han (s. 139) og fortsatte: "Quota- 
tion marks [...] are clear marks of the punning maneuver". Man skal kunne nære sig, når man analyserer, for ellers løber sproget af med én, og det er ikke den bedste form for analyse. Det skal dog siges til RS' ros, at hun inden for sin symptomatisk psykoanalytisk-tematiske læsestrategi er en god og pointeret analytiker.

I forordet skriver RS: "Kapitlerne kan fint læses uafhængigt af hinanden" (s. 7). Selvom RS på bedste vis henter sine pointer med fremefter i bogen og opsummerer og perspektiverer beundringsværdigt, er kapitlerne rigtigt nok ganske selvstændige, men også noget uegale - både $\mathrm{i}$ længden, i dybden og præsentationen af stoffet. I de fleste kapitler får vi således biografiske oplysninger om skuespillerne - Stallones opvækst synes særligt slem - men i tilfældene Clint Eastwood, Mel Gibson, Eddie Murphy, Bruce Willis hører vi intet. Hvorfor denne forskel? Bogen giver ikke noget svar.

Til slut et hjertesuk, som ikke kun drejer sig om RS's bog. Det handler om den amerikanske filmog medieteoris dominans på markedet. At RS kalder biograflærredet for en "skærm" (i en oversættelse af det engelske "screen", der kan betyde begge dele) er forkert; at hun kan skrive om den kvindelige actionhelt, at hun "går mainstream" er en irriterende anglicisme, men det er noget andet, mit hjerte sukker over: bortset fra nogle få danske tekster læses alt i engelske oversættelser. Det er i sig selv ikke noget problem, men det giver et misvisende indtryk af hvem, der skriver og hvilken sammenhæng, de skriver i, når vi f. eks. får at vide, at den tyske forsker Klaus Theweleit har skrevet en bog, der hedder Male Fantasies, når nu den oprindeligt er skrevet på tysk og hedder Männerphantasien - eller at René Girards skulle have udgivet en bog med titlen Violence and the Sacred på engelsk in the first place.

Uanset disse, ganske mange og i visse tilfælde ganske grundlæggende indvendinger mod Med vold og magt står det tilbage, at bogen er imponerende i sit omfang, forbilledlig i sit historiske overblik og pointeret i sine kategoriseringer.

Palle Schantz Lauridsen, lektor, ph.d., Institut for Nordisk Filologi, Kobenhavns Universitet 